DOI: https://doi.org/10.24127/ajpm.v8i1.1818

\title{
PENGEMBANGAN PEMBELAJARAN PENEMUAN TERBIMBING UNTUK MENINGKATKAN KEMAMPUAN BERPIKIR REFLEKTIF DAN KEMANDIRIAN BELAJAR SISWA
}

\author{
Nurwahid Juli Andrean ${ }^{1}$, Sri Hastuti Noer ${ }^{2}$, Asmiati $^{3}$ \\ ${ }^{1,2,3}$ Pendidikan Matematika, Universitas Lampung \\ E-mail: $\quad$ nurwahidandrean@gmail.com ${ }^{1)}$
}

Received 12 Februari 2019; Received in revised 6 May 2019; Accepted 13 June 2019

\begin{abstract}
Abstrak
Penelitian ini bertujuan untuk mengembangkan model pembelajaran penemuan terbimbing dan menguji efektivitasnya pada keterampilan berpikir reflektif matematis dan kemandirian belajar siswa. Tahap pengembangan ini dimulai dari studi pendahuluan, perencanaan, pengembangan produk awal, pengujian tahap awal, revisi produk awal, dan pengujian lapangan. Subjek penelitian ini adalah 30 siswa kelas VII.C dan 30 siswa VII.D di SMP Negeri 24 Bandar Lampung Tahun Akademik 2017/2018. Data penelitian diperoleh melalui observasi, wawancara, tes keterampilan berpikir reflektif matematis, dan angket kemandirian belajar siswa. Hasil tes lapangan menunjukkan bahwa kemampuan berpikir reflektif matematis dan pembelajaran Kemandirian siswa menggunakan pembelajaran penemuan terbimbing yang dikembangkan lebih tinggi daripada kemampuan berpikir reflektif matematika dan Kemandirian Belajar siswa yang tidak menggunakan pembelajaran penemuan terbimbing yang dikembangkan. Oleh karena itu dapat disimpulkan bahwa pembelajaran penemuan terbimbing yang dikembangkan efektif untuk meningkatkan keterampilan berpikir reflektif matematis dan kemandirian belajar siswa. Peningkatan kemampuan berpikir reflektif matematis siswa menggunakan pembelajaran penemuan terbimbing yang dikembangkan dikategorikan tinggi sedangkan peningkatan kemandirian belajar siswa dikategorikan sedang.
\end{abstract}

Kata kunci: penemuan terbimbing; belajar kemandirian; berpikir reflektif.

\begin{abstract}
This study aims to develop a model of guided discovery learning and test its effectiveness on mathematical reflective thinking skills and independence learning of student. This stage of development starts from preliminary studies, planning, initial product development, initial stage testing, initial product revision, and field testing. The subjects of this study were 30 students of class VII.C and 30 students of VII.D in SMP Negeri 24 Bandar Lampung 2017/2018 Academic Year. The research data was obtained through observation, interviews, tests of mathematical reflective thinking skills, and student Independence Learning questionnaires. The results of field tests show that the ability of mathematical reflective thinking and the Independence Learning of students using developed guided discovery learning is higher than the ability of mathematical reflective thinking and student Independence Learning that does not use developed guided discovery learning. Therefore it can be concluded that developed guided discovery learning is effective for improving mathematical reflective thinking skills and student Independence Learning. The increase in the ability of mathematical reflective thinking of students using developed Guided Discovery learning is categorized as high while the increase in student Independence Learning is categorized as being moderate.
\end{abstract}

Keywords: Guided Discovery; Independence Learning; Reflective Thinking.

\section{PENDAHULUAN}

Matematika mempunyai lima kemampuan mendasar yang merupakan standar kemampuan matematika yaitu pemecahan masalah (problem solving), penalaran dan bukti (reasoning and proof), komunikasi (communication), koneksi (connection) serta representasi (representation) (Widyawati, 2017). 
DOI: https://doi.org/10.24127/ajpm.v8i1.1818

Berdasarkan standar kemampuan yang ditentukan, pembelajaran matematika tidak hanya dituntut untuk menyampaikan materi dan menerima materi, tetapi harus mempunyai kemampuan dan keterampilan untuk mencapai keberhasilan dalam bidang matematika.

Hal ini sejalan dengan tujuan pembelajaran matematika yang ditetapkan kurikulum 2013. Dalam kurikulum 2013 diungkapkan bahwa kompetensi lulusan dalam bidang studi matematika adalah mengusung adanya peningkatan dan keseimbangan soft skills dan hard skills yang meliputi aspek kompetensi sikap, pengetahuan, dan keterampilan dalam bidang matematika.

Pembelajaran sebagai inti dari implementasi kurikulum dalam garis besarnya menyangkut tiga fungsi manajerial, yaitu perencanaan, pelaksanaan, dan penilaian. Dalam kaitannya dengan implementasi kurikulum, perencanaan dituangkan dalam program pembelajaran, yang berkaitan dengan cara bagaimana proses pembelajaran dilaksanakan untuk mewujudkan tujuan dan kompetensi secara efektif dan efisien. Hal tersebut tentu saja berkaitan erat dengan pembuatan dan pengambilan keputusan dalam kemampuan pemecahan masalah yang harus memberi gambaran tentang pelaksanaan pembelajaran yang diinginkan (As'ari, 2018)

Menurut Noer (2010) kemampuan berpikir reflekif merupakan jenis pemikiran yang melibatkan pemecahan masalah, perumusan kesimpulan, memperhitungkan hal-hal yang berkaitan, dan membuat keputusankeputusan disaat seseorang menggunakan keterampilan yang bermakna dan efektif untuk konteks tertentu dan jenis dari tugas berpikir. Hal itu selaras dengan Gurol (2011) menyatakan bahwa berpikir reflektif dapat dijadikan sebagai sarana untuk mendorong proses berpikir selama pemecahan masalah, karena memberikan kesempatan untuk belajar dan memikirkan strategi terbaik dalam proses pemecahan masalah.

Berdasarkan penjelasan diatas maka diketahui pentingnya peserta didik mengembangkan kemampuan berfikir reflektif. Salah satu yang harus dimiliki siswa dalam mengembangkan kemampuan berpikir reflektif adalah kemandirian belajar. Hal ini sesuai dengan pendapat Nindiasari (2013) bahwa terdapat keterkaitan antara kemampuan berpikir reflektif dengan kemandirian belajar siswa. Hal ini juga didukung dengan pendapat Egok (2017) yang menyatakan bahwa faktor kemampuan berpikir reflektif dan kemandirian belajar mempunyai pengaruh dalam pencapaian hasil belajar siswa. Kemandirian belajar merupakan suatu usaha yang dilakukan untuk melakukan aktivitas belajar dengan cara mandiri atas dasar motivasinya sendiri untuk menguasai suatu materi tertentu dalam memecahkan masalah.

Meninjau kemamandirian belajar, menurut Sugandi (2013) kemandirian belajar siswa merupakan hal yang turut menentukan berhasilnya suatu pengimplementasian pembelajaran dan turut menentukan pencapaian hasil belajar, hal ini cukup beralasan karena pembelajaran yang menciptakan situasi pemecahan masalah sangat diperlukan kemandirian siswa dalam belajar. Ditambahkan pula menurut Isnaeni, Fajriyah, Risky, Purwasih, \& Hidayat (2018) kemandirian belajar adalah kondisi aktifitas belajar siswa yang mandiri tidak tergantung pada orang lain. Dengan kemandirian belajar siswa dapat menilai kemampuan diri sendiri 
DOI: https://doi.org/10.24127/ajpm.v8i1.1818

akan memahami, menalar, dan mengerjakan suatu soal atau masalah.

Kemandirian belajar diperlukan agar siswa mempunyai tanggung jawab dalam mengatur dan mendisiplinkan dirinya, selain itu dalam mengembangkan kemampuan belajar atas kemauan sendiri. Kemandirian dalam belajar dapat diartikan sebagai kegiatan belajar aktif, yang didorong oleh niat atau motif untuk menguasai sesuatu kompetensi guna mengatasi sesuatu masalah, dan dibangun dengan bekal pengetahuan atau kompetensi yang telah dimiliki. Sikap tersebut perlu dimiliki oleh siswa sebagai peserta didik karena hal tersebut merupakan ciri dari kedewasaan orang terpelajar. Manfaat dari kemandirian siswa belum banyak dirasakan oleh para peserta didik.

Mengatasi permasalahan diatas terkait kemampuan berfikir reflektif kemandirian belajar peserta didik, banyak cara yang bisa digunakan dan dimanfaatkan oleh pendidik dalam proses pembelajaran. Salah satu model pembelajaran yang diharapkan mampu meningkatkan kemampuan berpikir reflektif dan kemandirian belajar siswa adalah model pembelajaran penemuan terbimbing. Khomsiatun \& Retnawati (2015) pembelajaran penemuan terbimbing adalah model pembelajaran yang menitik beratkan pada proses membangun pengetahuan. Kata penemuan sebagai metode pembelajaran merupakan penemuan yang dilakukan oleh siswa dalam belajar dan siswa tersebut menemukan sendiri sesuatu hal yang baru dalam dirinya melalui eksperimen.

Effendi (2012) menyatakan bahwa pembelajaran penemuan terbimbing merupakan suatu proses pembelajaran yang mengutamakan belajar aktif, berorientasi pada proses, menemukan sendiri, dan bersifat reflektif. Hal itu selaras dengan Agustyarini \& Jailani (2015) bahwa pembelajaran penemuan memungkinkan siswa belajar dengan melakukan, dalam hal ini siswa melakukan proses belajar dengan aktif, melakukan kegiatan menemukan konsep-konsep atau prinsip-prinsip secara mandiri sehingga siswa akan lebih memahami secara konseptual.

Selain itu menanggapi apa yang telah disampaikan oleh Miqdad \& Sumbawati (2017) bahwa banyaknya model pembelajaran yang dapat digunakan tidak serta merta secara instan dapat diterapkan dalam proses pembelajaran. hal ini karena terdapat kelemahan tertentu yang ada pada sebuah model pembelajaran tergantung tujuan yang akan hendak dicapai. Sama dengan yang dipaparkan oleh Ainiya (2018) agar lebih efektif, model pembelajaran yang sudah tersedia sebaik nya dikembangkan agar menciptakan lingkungan belajar yang melibatkan siswa secara aktif, sehingga siswa dapat menemukan sendiri konsepkonsep pembelajaran matematika yang telah diberikan oleh guru sebelumnya. Hal itu dilakukan untuk meningkatkan kemampuan berpikir reflektif matematis siswa, selain itu siswa dapat melatih dan meningkatkan kemandirian belajar mereka. Hal ini menyimpulkan bahwa perlunya perbaikan-perbaikan dan dikembangkan pembelajaran yang ada. Hal itu sesuai dengan Hanif, Ibrohim, \& Rohman (2016) yang mengemukakan bahwa pembelajaran menekankan pada pemahaman struktur atau ide-ide penting terhadap suatu disiplin ilmu melalui keterlibatan siswa secara aktif dalam pembelajaran, dan guru mendorong siswa untuk mendapatkan pengalaman dengan melakukan kegiatan yang memungkinkan siswa menemukan konsep-konsep atau prinsip-prinsip secara mandiri. 
DOI: https://doi.org/10.24127/ajpm.v8i1.1818

Tujuan penelitian ini adalah mengembangkan pembelajaran penemuan terbimbing untuk meningkatkan kemampuan berpikir reflektif dan kemandirian belajar siswa.

\section{METODE PENELITIAN}

Penelitian ini merupakan
penelitian dan pengembangan (Research and Development). Model pengembangan tang digunakan adalah model dari borg and gall adapun langkah-langkah yang digunakan adalah Research and information collecting, Planning, Develop preliminary form of product, Preliminary field testing, Main product revision, Main field testing, Operasional product revision, Operasional field testing, Final product revision, Dissemination and implementation (Sugiyono, 2016) Populasi dalam penelitian ini adalah seluruh siswa kelas VII SMP Negeri 24 Bandar Lampung tahun pelajaran 2018/2019 dan sampel diambil dengan teknik cluster random sampling. Penelitian dilakukan pada kelas VII C yang berjumlah 30 peserta didik dan kelas VII D yang berjumlah 30 peserta didik. Teknik pengumpulan data adalah teknik instrumen tes berupa soal dan teknik non tes berupa angket. Instumen tes berupa 5 soal essay yang digunakan untuk mengukur kemampuan berpikir reflektif matematis dan angket skala untuk mengukur kemandirian belajar siswa. Uji coba instrumen tes dilakukan pada kelas VIII SMP 24 Bandar
Lampung dengan responden 30 siswa untuk mengetahui validitas, reliabilitas, daya pembeda dan tingkat kesukaran. Untuk analisis data yang digunakan dalam penelitian ini adalah uji kesamaan dua rata-rata (uji $t$ ) dan uji ngain dengan klasifikasi (Noer, 2010) yaitu (1) kriteria tinggi jika g > 0,7, (2) kriteria sedang jika $0,3<\mathrm{g} \leq 0,7$, (3) kriteria rendah jika $\mathrm{g} \leq 0,3$.

\section{HASIL PENELITIAN DAN PEMBAHASAN}

Analisis uji normalitas dilakukan untuk mengetahui apakah data berdistribusi normal. Uji normalitas dilakukan dengan uji Kolmogorov Smirnov menggunakan software SPSS versi 20 dengan $\mathrm{Sig}>0,05$ diperoleh Sig $=0,200$ sehingga data berdistribusi normal. Karena data berdistribusi normal maka dilakukan uji kesamaan dua rata-rata (uji $t$ ) dan uji $n$-gain.

Hasil uji-t diperoleh bahwa nilai $t_{\text {hitung }} 2,79>t_{\text {tabel }} 2,00$ pada DF 58 dan nilai probabilitas nilai Sig. sebesar $0,007<0,05$ karena nilai Sig lebih kecil dari 0,05 maka hipotesis nol ditolak. Sehingga dapat disimpulkan bahwa ada perbedaan yang signifikan antara berpikir reflektif siswa menggunakan pembelajaran Penemuan Terbimbing dan LKPD yang dikembangkan dengan pembelajaran penemuan terbimbing yang tidak dikembangkan.

Selain itu pada uji N-gain dapat dilihat pada Tabel 1.

Tabel 1. Rekapitulasi hasil uji n-gain kemampuan berfikir reflektif

\begin{tabular}{lcccccc}
\hline $\begin{array}{c}\text { Kelompok } \\
\text { Kelas }\end{array}$ & $\begin{array}{c}\text { Jumlah } \\
\text { Siswa }\end{array}$ & $\begin{array}{c}\text { Indeks Gain } \\
\text { Terendah }\end{array}$ & $\begin{array}{c}\text { Indeks Gain } \\
\text { Tertinggi }\end{array}$ & $\begin{array}{c}\text { Simpangan } \\
\text { Baku }\end{array}$ & $\begin{array}{c}\text { Rata-Rata } \\
\text { N-gain }\end{array}$ & Kriteria \\
\hline Kelas & 30 & 0,24 & 0,94 & 0,70 & 0,70 & Tinggi \\
Eksperimen & 30 & 0,08 & 0,91 & 0,26 & 0,48 & Sedang \\
Kelas Kontrol & 30 & 0,40 & & & \\
\hline
\end{tabular}


DOI: https://doi.org/10.24127/ajpm.v8i1.1818

Berdasarkan Tabel 1. rata-rata Ngain kelas eksperimen adalah 0,71 , hal ini berarti bahwa peningkatan kemampuan berpikir reflektif siswa yang menggunakan pembelajaran penemuan terbimbing yang dikembangkan termasuk dalam peningkatan dengan kriteria tinggi, sedangkan peningkatan kemampuan berpikir reflektif siswa yang menggunakan pembelajaran penemuan terbimbing termasuk dalam peningkatan dengan kriteria sedang jika dilihat dari rata-rata $\mathrm{N}$-gain kelas kontrol yaitu sebesar 0,48 .

Setelah dilakukan uji-t dan uji $n$ gain pada kemampuan berfikir reflekstif peseta didik maka selanjutnya dilakukan uji pada kemandirian belajar peserta didik. Uji yang dilakukan yaitu uji t dan uji n-gain. Adapun hasil uji t pada kemampuan belajar peserta didik dapat dilihat pada Tabel 2.

Tabel 2. Rekapitulasi Hasil Uji-T Kemandirian Belajar Peserta Didik

\begin{tabular}{lcccc}
\hline \multicolumn{1}{c}{ Pembelajaran } & $\begin{array}{c}\text { Rata-rata } \\
\text { Ranking }\end{array}$ & $Z$ & Df & Sig. (2-tailed) \\
\hline $\begin{array}{l}\text { Pembelajaran dengan model penemuan } \\
\text { terbimbing yang dikembangkan }\end{array}$ & 91,63 & & & \\
$\begin{array}{l}\text { Pembelajaran dengan model peneuan } \\
\text { terbimbing biasa }\end{array}$ & 78,13 & $-0,517$ & 58 & 0,000 \\
\hline
\end{tabular}

Berdasarkan Tabel 2 terlihat bahwa nilai probabilitas (Sig.) kurang dari 0,05. Ini berarti bahwa hipotesis nol ditolak. Sehingga dapat disimpulkan bahwa ada perbedaan yang signifikan antara siswa yang mengikuti pembelajaran penemuan terbimbimbing yang dikembangkan dengan kemandirian belajar siswa yang mengikuti pembelajaran penemuan terbimbimbing biasa. Dengan demikian dapat ditarik kesimpulan bahwa pengembangan pembelajaran penemua terbimbing efektif untuk meningkatkan kemandirian belajar siswa.

Selanjutnya hasil uji n-gain kemandirian belajar peserta didik dapat dilihat pada Tabel 3.

Tabel 3. Rekapitulasi Hasil Uji N-Gain

\begin{tabular}{lccccc}
\hline Kelompok & $\begin{array}{c}\text { Banyak } \\
\text { Siswa }\end{array}$ & Rata-rata & $\begin{array}{c}\text { Simpangan } \\
\text { baku }\end{array}$ & $\begin{array}{c}\text { Indeks Gain } \\
\text { Terendah }\end{array}$ & $\begin{array}{c}\text { Indeks Gain } \\
\text { Tertinggi }\end{array}$ \\
\hline Eksperimen & 30 & 0,37 & 0,25 & $-0,20$ & 0,67 \\
Kontrol & 30 & 0,27 & 0,06 & $-0,2$ & 0,33 \\
\hline
\end{tabular}

Berdasarkan Tabel 3. memperlihatkan bahwa rata-rata kemandirian belajar siswa yang yang mengikuti pembelajaran dengan model penemuan terbimbing yang dikembangkan lebih tinggi daripada penemuan terbimbing siswa yang menggikuti pembelajaran dengan model penemuan terbimbing biasa.

Tidak mudah dalam mengembangkan bahan ajar dengan cara penemuan terbimbing khususnya dalam meningkat kemampuan berfikir reflektif dan kemamndirian belajar peserta didik. Menurut Suhendri, (2015) dalam menerapkan model tebimbing haruslah dilakukan secara kontinu. Hal ini sejalan dengan menurut Agustyarini \& Jailani (2015) dalam menerapkan suatu model atau pun bahan ajar yang mendukung kemenarikannya dalam pembelajaran haruslah dilakukan secara 
terus menerus agar pendidik lebih terbiasa. Perangkat pembelajaran yang memiliki standar kevalidan, kepraktisan, dan keefektifan disebabkan oleh beberapa faktor. Faktor pertama adalah dirumuskannya perangkat pembelajaran penemuan terbimbing yang sesuai dengan langkah pembelajaran sehingga tidak menimbulkan ketimpangan antara proses pembelajaran dan media yang digunakan. Kedua, pada pembelajaran penemuan terbimbing siswa harus menganalisis masalah sendiri, sehingga dapat memahami suatu konsep dan bisa menghubungkannya dengan konsep lain secara general. Penanaman konsep secara mendalam ini membuat pembelajaran matematika lebih bermakna dalam ingatan siswa. Hal ini sesuai dengan teori kontruktivisme bahwa pendidik tidak hanya sekedar memberikan pengetahuan kepada siswa. Siswa harus membangun sendiri pengetahuan di dalam benaknya, sehingga pembelajaran matematika lebih bermakna (Yuliyanto \& Jailani, 2014).

\begin{tabular}{llr}
\multicolumn{2}{c}{ Berdasarkan uji } & hipotesis \\
diperoleh bahwa & pembelajaran \\
menggunakan tahapan & penemuan
\end{tabular} terbimbing yang dikembangkan terbukti efektif digunakan dalam meningkatakan kemandirian belajar siswa. Peningkatan kemandirian belajar terjadi karena adanya interaksi sosial antar kelompok, kepercayaan diri siswa mulai terlihat dalam bekerja sama saat menyelesaikan masalah. Siswa juga dapat mengidentifikasi dirinya dengan teman kelompoknya sehingga proses kepercayaan dirinya dapat berkembang.

Dari kelima indikator kemandirian belajar tersebut, inisiatif dan kreatif indikator yang mengalami peningkatan. Hal ini dapat dilihat ketika siswa melakukan diskusi kelompok, siswa bekerja sama dengan kelompoknya dan mampu menjelaskan materi yang mereka pahami kepada teman dalam kelompoknya tersebut. Interaksi siswa dengan teman sekelompoknya tersebut akan membentuk sebuah pandangan bagaimana ia berperan dalam kelompoknya atau membuat siswa lebih mengenal bagaimana kemampuan yang ia miliki dibandingkan teman-temannya. Sebagian siswa memiliki pandangan positif terhadap kemampuannya namun ada juga yang memiliki pandangan yang negatif terhadap kemampuan yang ia miliki. Pandangan negatif tersebut dapat berubah menjadi positif ketika siswa bersama kelompoknya merasa telah mampu menyelesaikan permasalahan dengan baik (Ayuningtyas, 2015).

Kemandirian belajar siswa yang positif juga terbentuk jika orang lain memberikan penilaian yang positif terhadap kemampuan yang dimilikinya. Hal ini terlihat, pada saat siswa mempresentasikan hasil diskusi kelompok atau mengemukakan ide/pendapatnya kemudian guru memberikan apresiasi/penghargaan verbal berupa pujian atau tepuk tangan kepada siswa tersebut, maka siswa tersebut merasa bahwa orang lain menghargai kemampuan yang ia miliki sehingga ia akan lebih percaya diri dan memiliki kemandirian belajar yang positif. Seperti menurut Ulya, Irawati, \& Maulana, (2016) motivasi yang akan diberikan kepada peserta didik akan mempengaruhi semangat belajar bagi peserta didik untuk pertemuan yang akan dating dalam pembelajaran.

\section{KESIMPULAN DAN SARAN}

Kesimpulan hasil penelitian ini adalah pengembangan pembelajaran penemuan terbimbing untuk meningkatkan kemampuan berpikir reflektif matematis dan kemandirian belajar siswa dilakukan melalui analisis 
kebutuhan, pengembangan produk, validasi ahli, uji skala kecil dan uji lapangan. Produk pembelajaran Penemuan Terbimbing untuk meningkatkan kemampuan berpikir reflektif matematis dan kemandirian belajar siswa layak untuk diimplementasikan setelah memenuhi kriteria valid (melalui validasi ahli) dan praktis (melalui pengguna serta melalui uji coba).

Pengembangan pembelajaran penemuan terbimbing efektif untuk meningkatkan kemampuan berpikir reflektif matematis dan kemandirian belajar siswa. Hasil pembelajaran penemuan terbimbing yang dikembangkan menghasilkan pengembangan pembelajaran yang lebih efektif dibandingkan dengan pembelajaran penemuan terbimbing biasa. Hal ini dapat dilihat dari keaktifan siswa selama mengikuti kegiatan pembelajaran.

Saran yang dapat dipertimbangkan dalam pengembangan penemuan terbimbing, yaitu (1) Guru dapat memanfaatkan produk pengembangan pembelajaran Penemuan Terbimbing yang diharapkan dapat dijadikan alternatif untuk meningkatkan kemampuan berpikir reflektif matematis dan kemandirian belajar siswa pada materi Himpunan Kelas VII SMP. (2) Pengembangan pembelajaran yang dikembangkan hanya terbatas pada materi Himpunan Kelas VII SMP untuk memfasilitasi peningkatan kemampuan berpikir reflektif matematis dan kemandirian belajar siswa, maka disarankan kepada pembaca atau peneliti lain yang ingin mengembangkan penelitian lanjutan mengenai pengembangan pembelajaran penemuan terbimbing hendaknya melakukan pengembangan pada ruang lingkup materi yang berbeda, pada tingkat satuan pendidikan yang berbeda, atau dalam kemampuan lainnya yang harus dimiliki siswa dalam pembelajaran matematika.

\section{DAFTAR PUSTAKA}

Agustyarini, Y., \& Jailani, J. (2015). Pengembangan bahan ajar matematika dengan pendekatan kontekstual dan metode penemuan terbimbing untuk meningkatkan EQ dan SQ siswa SMP Akselerasi. Jurnal Riset Pendidikan Matematika, 2(1), 135-147.

Ainiya, S. K. (2018). Pengembangan perangkat pembelajaran Matematika Bridging Analogy untuk mengatasi miskonsepsi siswa pada materi Bangun Ruang Sisi Datar di SMPN 2 Sidoarjo (PhD Thesis). UIN Sunan Ampel Surabaya.

As'ari, A. R. (2018). Pembelajaran Matematika untuk Pengembangan Karakter Peserta Didik. Prosiding Sendika, 4(1).

Ayuningtyas, A. D. (2015). Eksperimentasi Model Pembelajaran Kooperatif Tipe Think Pair Share (Tps) Ditinjau Dari Kemandirian Belajar Siswa Kelas VIII SMP NEGERI DI KOTA YOGYAKARTA. JIPM (Jurnal Ilmiah Pendidikan Matematika), 3(2).

Effendi, L. A. (2012). Pembelajaran Matematika Dengan Metode Penemuan Terbimbing Untuk Meningkatkan Kemampuan Representasi Dan Pemecahan Masalah Matematis Siswa SMP. Jurnal Penelitian Pendidikan, 13(2).

Egok, A. S. (2017). Kemampuan Berpikir Kritis dan Kemandirian Belajar dengan Hasil Belajar Matematika. Jurnal Pendidikan Dasar UNJ, 7(2), 186-199. 
DOI: https://doi.org/10.24127/ajpm.v8i1.1818

Gurol, A. (2011). Determining the reflective thinking skills of preservice teachers in learning and teaching process. Energy Education Science and Technology Part B: Social and Educational Studies, 3(3), 387402.

Hanif, H., Ibrohim, I., \& Rohman, F. (2016). Pengembangan Perangkat Pembelajaran Biologi Materi Plantae Berbasis Inkuiri Terbimbing Terintegrasi Nilai Islam Untuk Meningkatkan Pemahaman Konsep Siswa SMA. Jurnal Pendidikan: Teori, Penelitian, dan Pengembangan, 1(11), 2163-2171.

Isnaeni, S., Fajriyah, L., Risky, E. S., Purwasih, R., \& Hidayat, W. (2018). Analisis Kemampuan Penalaran Matematis dan Kemandirian Belajar Siswa SMP pada Materi Persamaan Garis Lurus. Journal of Medives: Journal of Mathematics Education IKIP Veteran Semarang, 2(1), 107-116. https://doi.org/10.31331/medives. v2i1.528

Khomsiatun, S., \& Retnawati, H. (2015). Pengembangan Perangkat Pembelajaran Dengan Penemuan Terbimbing Untuk Meningkatkan Kemampuan Pemecahan Masalah. Jurnal Riset Pendidikan Matematika, 2(1), 92-106. https://doi.org/10.21831/jrpm.v2i1 .7153

Miqdad, A. D., \& Sumbawati, M. S. (2017). Analisis Pengembangan Model Pembelajaran Berbasis Project Based Learning Dengan Berbantu Media Audio Visual Videoscribe dalam Pembelajaran Komputer dan Jaringan Dasar Kelas X SMK Unitomo Surabaya. IT-EDU, 2(02).
Nindiasari, H. (2013). Meningkatkan Kemampuan Dan Disposisi Berpikir Reflektif Matematis Serta Kemandirian Belajar Siswa Sma Melalui Pembelajaran Dengan Pendekatan Metakognitif (Phd, Universitas Pendidikan Indonesia).

http://repository.upi.edu/3659/10/ D_MTK 0908697_Appendix.pdf

Noer, S. H. (2010). Peningkatan Kemampuan Berpikir Kritis, Kreatif, Dan Reflektif (K2r) Matematis Siswa Smp Melalui Pembelajaran Berbasis Masalah (Phd, Universitas Pendidikan Indonesia). Diambil dari http://repository.upi.edu

Sugandi, A. I. (2013). Pengaruh Pembelajaran Berbasis Masalah Dengan Setting Kooperatif Jigsaw Terhadap Kemandirian Belajar Siswa SMA. Infinity Journal, 2(2), 144-155. https://doi.org/10.22460/infinity.v 2i2.p144-155

Sugiyono, M. (2016). Kualitataif dan R\&D, Bandung: Alfabeta. Sugiyono, Metode Penelitian Kuantitatif kualitatif dan $R \& D$ Bandung: Alfabeta.

Suhendri, H. (2015). Penerapan model pembelajaran konstruktif berbasis penemuan terbimbing dalam meningkatkan hasil belajar matematika. Formatif: Jurnal Ilmiah Pendidikan MIPA, 3(3).

Ulya, I. F., Irawati, R., \& Maulana, M. (2016). Peningkatan Kemampuan Koneksi Matematis Dan Motivasi Belajar Siswa Menggunakan Pendekatan Kontekstual. Jurnal Pena Ilmiah, 1(1), 121-130.

Widyawati, S. (2017). Pengaruh Kemampuan Koneksi Matematis Siswa terhadap Prestasi Belajar Matematika Ditinjau dari Gaya Belajar pada Materi Bangun 
AKSIOMA: Jurnal Program Studi Pendidikan Matematika

DOI: https://doi.org/10.24127/ajpm.v8i1.1818

Ruang Sisi Datar Siswa Kelas IX SMP di Kota Metro. Iqra': Jurnal Kajian Ilmu Pendidikan, 1(1), 4768.

Yuliyanto, Y., \& Jailani, J. (2014). Pengembangan perangkat pembelajaran geometri SMP menggunakan metode penemuan terbimbing pada kelas VIII Semester II. Jurnal Riset Pendidikan Matematika, 1(1), 127-138. 